\title{
ULTRAFILTRABLE MAGNESIUM IN HYPERTHYROIDISM
}

\author{
BY LOUIS J. SOFFER, D. ALFRED DANTES,1 EDWARD B. GROSSMAN, \\ HARRY SOBOTKA, AND MILDRED D. JACOBS \\ (From the Medical Service of Dr. George Baehr and the Division of Laboratories of The Mount \\ Sinai Hospital, New York City)
}

(Received for publication May 16, 1939)

The following report is concerned with the study of magnesium metabolism in clinical and experimental hyperthyroidism. This first communication deals primarily with the ratio of diffusible magnesium to total serum magnesium in the hyperthyroid state.

The general question of relationship of total serum magnesium to its ultrafiltrable fraction in 8 normal individuals has been discussed by Watchorn and McCance (1). They found that normally approximately 25 per cent of the total serum magnesium is non-diffusible. These authors suggest that there are probably 2 factors which play a part in determining the amount of ionizable magnesium. The bound magnesium may be in combination either with the protein in the serum or with the serum phosphatides. These acids, which behave similarly to protein, are present in adequate quantities to bind considerable amounts of magnesium. Brull (2) and Scholtz (3) also believe that both calcium and magnesium form colloidal phosphate complexes.

\section{METHOD}

The total serum magnesium was determined by the method of Briggs (4). The serum proteins were precipitated with trichloracetic acid. It was found that little, if any, magnesium was carried down with the protein flocculum. To $10 \mathrm{cc}$. of protein free filtrate were added $1 \mathrm{cc}$. of 20 per cent sodium acetate, 6 to 8 drops of 0.016 per cent bromcresol green, and 1 cc. of 4 per cent ammonium oxalate. The $\mathrm{pH}$ of the solution was adjusted to 5.0 by addition of ammonium hydroxide. The mixture was allowed to stand overnight, and the precipitated calcium oxalate then separated by centrifugation. To the decanted supernatant fluid and washings were added $1 \mathrm{cc}$. of 2 per cent potassium dihydrogen phosphate,

\footnotetext{
1 Aided by a grant from the Herbert Celler Fund.
}

and $1 \mathrm{cc}$. of concentrated ammonia solution. After the mixture had again been allowed to stand overnight, the precipitate was separated by centrifugation and washed with a solution containing $200 \mathrm{cc}$. of 95 per cent alcohol and $50 \mathrm{cc}$. of concentrated ammonia solution per liter. The precipitated magnesium ammonium phosphate was dried and determined according to the method of Kuttner and Lichtenstein (5) by comparison of the color developed on addition of 7.5 per cent sodium molybdate and 0.2 per cent stannous chloride with that of a standard phosphate stock solution.

For the determination of diffusible magnesium, serum was ultrafiltered through a " 600 " Cellophane membrane under a pressure of 80 pounds nitrogen per square inch. The magnesium content of the ultrafiltrate was determined as described above, except that the protein precipitation with trichloracetic acid was omitted.

\section{RESULTS}

Total and ultrafiltrable magnesium determinations were made in normal individuals, in patients with neurocirculatory asthenia, various muscular dystrophies, and in patients with clinically well defined hyperthyroidism. In many of the latter group, determinations were made before and after the administration of Lugol's solution and after operation.

In Table I are presented the results obtained in 14 normal individuals. It was found that the percentage of the total serum magnesium which is non-diffusible varied in these individuals from 3.1 to 22.1 per cent, the largest number of the group falling between 10 and 19 per cent. The total serum magnesium varied between 2.12 and $2.76 \mathrm{mgm}$. per cent, with one exception of 4.30 mgm. per cent.

In Table II are included the data obtained in patients with neurocirculatory asthenia. The 
TABLE I

Total serum magnesium and percentage of bound magnesium in normal individuals

\begin{tabular}{c|c|c|c|c}
\hline \hline Number & $\begin{array}{c}\text { Total } \\
\text { protein }\end{array}$ & $\begin{array}{c}\text { Total } \\
\text { magnesium }\end{array}$ & $\begin{array}{c}\text { Magnesium } \\
\text { in } \\
\text { ultra- } \\
\text { filtrate }\end{array}$ & $\begin{array}{c}\text { Percentage } \\
\text { of } \\
\text { bound } \\
\text { magnesium }\end{array}$ \\
\cline { 2 - 4 } & $\begin{array}{c}\text { grams } \\
\text { per cent }\end{array}$ & $\begin{array}{c}\text { mgm. per } \\
100 \text { cc. }\end{array}$ & $\begin{array}{c}\text { mgm. per } \\
100 \text { cc. }\end{array}$ & per cent \\
1 & 7.0 & 2.12 & 1.83 & 13.7 \\
2 & 8.4 & 2.55 & 2.47 & 3.1 \\
3 & 8.2 & 2.36 & 2.06 & 12.7 \\
4 & 7.8 & 2.27 & 2.19 & 3.5 \\
5 & 7.5 & 2.15 & 1.72 & 20.0 \\
6 & 7.0 & 2.76 & 2.20 & 20.3 \\
7 & & 4.30 & 3.75 & 12.8 \\
8 & & 2.23 & 2.01 & 9.9 \\
9 & & 2.46 & 2.00 & 18.7 \\
10 & & 2.33 & 1.93 & 17.2 \\
11 & & 2.33 & 2.17 & 6.9 \\
12 & & 2.58 & 2.04 & 20.9 \\
13 & & 2.60 & 2.04 & 21.5 \\
14 & & 2.21 & 1.72 & 22.1 \\
\hline Average & 7.6 & 2.52 & 2.15 & 14.5 \\
\hline
\end{tabular}

TABLE II

Total serum magnesium and percentage of bound magnesium in neurocirculatory asthenia and various myopathies

\begin{tabular}{|c|c|c|c|}
\hline Number & $\begin{array}{c}\text { Total } \\
\text { magnegium }\end{array}$ & $\begin{array}{c}\text { Magnesium } \\
\text { in ultra- } \\
\text { filtrate }\end{array}$ & $\begin{array}{c}\text { Percentage of } \\
\text { bound } \\
\text { magnesium }\end{array}$ \\
\hline & mgm. per 100 cc. & mgm. per $100 \mathrm{cc}$. & per cent \\
\hline \multicolumn{4}{|c|}{ NEUROCIRCULATORY ASTHENIA } \\
\hline $\begin{array}{l}1 \\
2 \\
3 \\
4 \\
5\end{array}$ & $\begin{array}{l}2.60 \\
2.33 \\
2.47 \\
2.96 \\
3.48\end{array}$ & $\begin{array}{l}2.10 \\
1.91 \\
2.02 \\
2.35 \\
3.16\end{array}$ & $\begin{array}{r}19.2 \\
18.0 \\
18.2 \\
20.6 \\
9.2\end{array}$ \\
\hline
\end{tabular}

PROGRESSIVE MUSCULAR DYSTROPHY (HYPERTROPHIC)

\begin{tabular}{|c|c|c|c|}
\hline $\begin{array}{l}1 \\
2\end{array}$ & $\begin{array}{l}2.60 \\
2.35\end{array}$ & $\begin{array}{l}1.85 \\
2.16\end{array}$ & $\begin{array}{r}28.8 \\
8.1\end{array}$ \\
\hline \multicolumn{4}{|c|}{ MYASTHENIA GRAVIS } \\
\hline $\begin{array}{l}1 \\
2 \\
3 \\
4 \\
5\end{array}$ & $\begin{array}{l}2.34 \\
2.51 \\
2.70 \\
2.67 \\
2.33\end{array}$ & $\begin{array}{l}2.09 \\
1.96 \\
2.28 \\
2.04 \\
2.17\end{array}$ & $\begin{array}{r}10.7 \\
21.9 \\
15.5 \\
23.6 \\
6.9\end{array}$ \\
\hline
\end{tabular}

percentage of bound magnesium varied between 9.1 and 20.6 per cent, while the total serum magnesium varied between 2.33 and $3.48 \mathrm{mgm}$. per cent.

The results obtained in this group are almost identical with those found in the normal individ- uals. The basal metabolic readings of the patients with neurocirculatory asthenia were all well within the normal limits. It is frequently difficult to distinguish clinically between this group and patients with definite hyperthyroidism. But, as we shall see in the subsequent tables, the behavior of the serum magnesium in normal individuals and in patients with neurocirculatory asthenia is entirely different from that in hyperthyroidism.

In Table II are also presented the results obtained in 7 patients with various myopathies. Five of these patients have myasthenia gravis, while 2 have progressive muscular dystrophy. Again, it will be seen that the results in these patients are identical with those of the normal group, with the exception of one patient with progressive muscular dystrophy who showed some elevation of the percentage of bound magnesium.

The results obtained in patients with Graves' disease were striking. For this study 31 instances of hyperthyroidism of varying intensity were investigated. In each instance the clinical diagnosis was confirmed by microscopic study of the thyroid gland removed at operation. In 13 of these 31 patients total and ultrafiltrate serum magnesium determinations were made before and after the administration of Lugol's solution, in 12 control and postoperative studies were conducted, and finally in 6 instances determinations were made before the administration of iodine, after the administration of Lugol's solution, and after operation. The postoperative specimens were collected 10 days after the operation just prior to discharge from the hospital.

In Table III are presented the data obtained in the 31 patients with hyperthyroidism. The basal metabolic rate in these patients varied between plus 30 and plus 106 per cent. The total serum magnesium in these patients, directly on admission to the hospital, varied between 1.85 and 2.96 mgm. per cent, while the percentage bound varied between 21.5 and 61.6 per cent. Overlapping of the percentages of bound magnesium in the normal controls with those in the patients with hyperthyroidism occurred in only 2 instances. The bound magnesium in most of the normals was less than 20 per cent, while among patients with hyperthyroidism values over 30 per cent prevailed. No significant change of total serum 
TABLE III

Total serum magnesium and percentage of bound magnesium in patients with hyperthroidism

\begin{tabular}{|c|c|c|c|c|c|}
\hline Number & $\begin{array}{c}\text { Basal } \\
\text { metabo- } \\
\text { lic rate }\end{array}$ & $\begin{array}{c}\text { Total } \\
\text { protein }\end{array}$ & $\begin{array}{c}\text { Total } \\
\text { Mag- } \\
\text { nesium }\end{array}$ & $\begin{array}{c}\text { Magnesium } \\
\text { in ultra- } \\
\text { filtrate }\end{array}$ & $\begin{array}{l}\text { Percentage } \\
\text { of bound } \\
\text { magnesium }\end{array}$ \\
\hline $\begin{array}{r}1 \\
2 \\
3 \\
4 \\
5 \\
6 \\
7 \\
8 \\
9 \\
10 \\
11 \\
12 \\
13 \\
14 \\
15 \\
16 \\
17 \\
18 \\
19 \\
20 \\
21 \\
22 \\
23 \\
24 \\
25 \\
26 \\
27 \\
28 \\
29 \\
30 \\
31\end{array}$ & $\begin{array}{l}\text { per cent } \\
+45 \\
+66 \\
+43 \\
+40 \\
+41 \\
+43 \\
+30 \\
+47 \\
+106 \\
+49 \\
+38 \\
+41 \\
+56 \\
+56 \\
+60 \\
+50 \\
+37 \\
+30 \\
+50 \\
+48 \\
+42 \\
+40 \\
+46 \\
+36 \\
+56 \\
+60 \\
+40 \\
+34\end{array}$ & 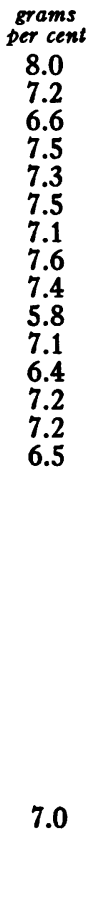 & \begin{tabular}{|c} 
mgm. per \\
100 cc. \\
2.16 \\
2.64 \\
2.10 \\
1.85 \\
2.54 \\
2.79 \\
2.64 \\
2.11 \\
2.24 \\
2.22 \\
2.02 \\
2.60 \\
2.30 \\
2.62 \\
2.46 \\
2.68 \\
2.59 \\
2.42 \\
2.35 \\
2.44 \\
2.41 \\
2.30 \\
2.59 \\
2.71 \\
2.56 \\
2.38 \\
2.55 \\
2.75 \\
2.41 \\
2.31 \\
2.96
\end{tabular} & $\begin{array}{c}\text { mgm. per } \\
100 \text { cc. } \\
1.15 \\
1.74 \\
0.86 \\
0.71 \\
1.41 \\
2.02 \\
1.91 \\
1.60 \\
1.39 \\
1.49 \\
1.08 \\
1.35 \\
1.38 \\
1.52 \\
1.69 \\
1.37 \\
1.72 \\
1.60 \\
1.54 \\
1.61 \\
1.90 \\
1.70 \\
1.65 \\
1.87 \\
1.69 \\
1.72 \\
1.71 \\
1.72 \\
1.73 \\
1.80 \\
2.08\end{array}$ & $\begin{array}{c}\text { per cent } \\
46.7 \\
34.1 \\
60.0 \\
61.6 \\
44.4 \\
27.6 \\
27.6 \\
24.1 \\
38.0 \\
32.8 \\
46.5 \\
48.0 \\
41.2 \\
42.0 \\
31.3 \\
49.8 \\
30.0 \\
33.8 \\
34.4 \\
33.6 \\
21.5 \\
26.0 \\
36.3 \\
31.0 \\
34.0 \\
27.7 \\
32.9 \\
37.4 \\
28.2 \\
22.2 \\
30.0\end{array}$ \\
\hline Average & & 7.1 & 2.44 & 1.58 & 36.0 \\
\hline
\end{tabular}

magnesium occurred in patients with Graves' disease as compared to the normals.

It is evident, therefore, that in hyperthyroidism there occurs a marked increase in the amount of circulating magnesium which is bound, at the expense of the diffusible fraction. There is no correlation between the percentage of bound magnesium and the basal metabolic rate, perhaps due to the fact that the metabolic rate was determined very shortly after admission to the hospital ward and may not represent the true basal rate.

In 13 patients, the total and bound magnesium in the blood was determined before and after the administration of Lugol's solution (Table IV). There is no essential change in the total serum magnesium before and after adequate administration of iodine, but a considerable change occurred in the non-filtrable fraction. Thus, before the administration of Lugol's solution the bound mag-
TABLE IV

Total serum magnesium and percentage of bound magnesium in hyperthyroidism before treatment, after the administration of Lugol's solution and after operation

\begin{tabular}{|c|c|c|c|c|c|c|c|c|c|c|c|}
\hline \multirow{3}{*}{$\begin{array}{l}\text { Cur- } \\
\text { rent } \\
\text { num- } \\
\text { ber }\end{array}$} & \multicolumn{4}{|c|}{ Before treatment } & \multicolumn{4}{|c|}{ After lugolisation } & \multirow{2}{*}{\multicolumn{3}{|c|}{$\begin{array}{c}\text { After operation } \\
\text { Magnesium }\end{array}$}} \\
\hline & \multirow[b]{2}{*}{$\begin{array}{l}\text { Bassal } \\
\text { meta- } \\
\text { bolic } \\
\text { rate }\end{array}$} & \multicolumn{3}{|c|}{ Magnesium } & \multirow[b]{2}{*}{$\begin{array}{l}\text { Basal } \\
\text { meta- } \\
\text { bolic } \\
\text { rate }\end{array}$} & \multicolumn{3}{|c|}{ Magneaium } & & & \\
\hline & & 勇 & 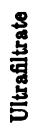 & 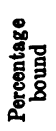 & & 要 & $\begin{array}{l}\frac{8}{4} \\
\text { 营 } \\
\text { 营 } \\
\text { 点 }\end{array}$ & 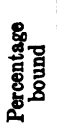 & 吿 & 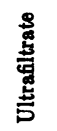 & 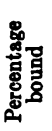 \\
\hline $\begin{array}{l}12 \\
13 \\
15 \\
19 \\
21 \\
26 \\
29\end{array}$ & $\begin{array}{l}\text { per } \\
\text { cent } \\
\\
\\
+41 \\
+56 \\
+60 \\
+30 \\
+30 \\
+50 \\
+36 \\
+60\end{array}$ & $\begin{array}{c}\text { mom. } \\
\text { per } \\
100 \\
\text { cc. } \\
2.60 \\
2.30 \\
2.46 \\
2.35 \\
2.41 \\
2.38 \\
2.41\end{array}$ & $\begin{array}{c}\text { mom. } \\
\text { per } \\
100 \\
\text { cc. } \\
1.35 \\
1.38 \\
1.69 \\
1.54 \\
1.90 \\
1.72 \\
1.73\end{array}$ & $\begin{array}{c}\text { per } \\
\text { cent } \\
48.0 \\
41.2 \\
31.3 \\
34.4 \\
21.5 \\
27.2 \\
28.2\end{array}$ & $\begin{array}{c}\text { per } \\
\text { cent } \\
\\
+29 \\
+30 \\
+32 \\
+32 \\
+12 \\
+22 \\
+21 \\
+29\end{array}$ & $\begin{array}{c}\text { mom. } \\
\text { per } \\
100 \\
\text { cc. } \\
2.40 \\
2.38 \\
2.40 \\
2.31 \\
2.25 \\
2.85 \\
2.50\end{array}$ & $\begin{array}{c}\text { mom. } \\
\text { per } \\
100 \\
\text { cc. } \\
1.81 \\
1.66 \\
1.66 \\
1.82 \\
1.92 \\
2.17 \\
1.91\end{array}$ & $\begin{array}{c}\text { per } \\
\text { cent } \\
\\
24.4 \\
30.0 \\
30.8 \\
21.2 \\
14.6 \\
22.1 \\
23.6\end{array}$ & $\begin{array}{c}\text { mom. } \\
\text { per } \\
100 \\
\text { cc. }\end{array}$ & $\begin{array}{l}\text { mgm. } \\
\text { per } \\
100 \\
c c .\end{array}$ & $\begin{array}{l}\text { per } \\
\text { cent }\end{array}$ \\
\hline $\begin{array}{l}14 \\
16 \\
22 \\
24 \\
27 \\
31\end{array}$ & $\begin{array}{r}+56 \\
+50 \\
+48 \\
+40 \\
+34\end{array}$ & $\begin{array}{l}2.62 \\
2.68 \\
2.30 \\
2.71 \\
2.55 \\
2.96\end{array}$ & $\begin{array}{l}1.52 \\
1.37 \\
1.70 \\
1.87 \\
1.71 \\
2.08\end{array}$ & $\begin{array}{l}42.0 \\
49.8 \\
26.0 \\
31.0 \\
32.9 \\
30.0\end{array}$ & $\begin{array}{r}+32 \\
+24 \\
+30 \\
+18 \\
+18\end{array}$ & $\begin{array}{l}2.59 \\
2.57 \\
2.74 \\
2.65 \\
3.03 \\
2.34\end{array}$ & $\begin{array}{l}1.76 \\
1.82 \\
2.35 \\
1.81 \\
2.03 \\
2.20\end{array}$ & \begin{tabular}{|r}
32.0 \\
29.5 \\
14.5 \\
31.0 \\
33.0 \\
6.0
\end{tabular} & $\begin{array}{l}2.55 \\
2.83 \\
2.00 \\
1.91 \\
2.63 \\
2.67\end{array}$ & $\begin{array}{l}2.10 \\
2.33 \\
1.64 \\
1.91 \\
2.10 \\
2.43\end{array}$ & $\begin{array}{c}17.4 \\
17.6 \\
18.0 \\
0 \\
20.1 \\
9.0\end{array}$ \\
\hline $\begin{array}{r}9 \\
10 \\
11 \\
18 \\
25 \\
30\end{array}$ & $\begin{array}{r}+106 \\
+49 \\
+38 \\
+37 \\
+46 \\
+40\end{array}$ & $\begin{array}{l}2.24 \\
2.22 \\
2.02 \\
2.42 \\
2.56 \\
2.31\end{array}$ & $\begin{array}{l}1.39 \\
1.49 \\
1.08 \\
1.60 \\
1.69 \\
1.80\end{array}$ & $\begin{array}{l}38.0 \\
32.8 \\
46.5 \\
33.8 \\
34.0 \\
22.2\end{array}$ & & & & & $\begin{array}{l}2.85 \\
2.88 \\
2.43 \\
2.68 \\
2.78 \\
3.10\end{array}$ & $\begin{array}{l}2.45 \\
2.29 \\
2.00 \\
2.68 \\
2.25 \\
2.76\end{array}$ & $\begin{array}{c}14.0 \\
20.5 \\
17.6 \\
0 \\
19.0 \\
11.0\end{array}$ \\
\hline
\end{tabular}

nesium varied between 21.5 and 49.8 per cent, while afterwards the bound fraction varied between 6.0 and 33.0 per cent. After operation the results were even more striking. In 12 patients (Table IV) studies were conducted when they were first admitted to the hospital before receiving iodine, and again just before discharge from the hospital after subtotal thyroidectomy. The non-diffusible fraction before operation varied between 22.2 and 49.8 per cent, while postoperatively it varied between 0.0 and 20.5 per cent, a return to normal levels. This is again demonstrated in those 6 patients in whom determinations were made during the control period, after the administration of Lugol's solution, and after operation (Table IV). After iodine administration, some drop occurred in the percentage of bound magnesium which dropped still further to normal levels after the operation.

During the period of this study, we have had 2 patients with myxedema. In both patients the basal metabolic rate was minus 40 and in both instances there was no circulating bound magnesium, the direct opposite of the finding in pa- 
tients with hyperthyroidism. The total serum magnesium in the patients with myxedema was well within the normal range.

The mechanism which produces an increase in the percentage of bound magnesium in hyperthyroidism is obscure, and one may raise the question as to whether the blood colloids play some part in the binding mechanism. The amount of blood protein in our series, however, was no greater in patients with hyperthyroidism than in the normal individuals, so that we must postulate some change in the nature of the blood proteins to explain the increase in the binding mechanism. To investigate this phase we performed the following experiments: from 50 to $200 \mathrm{mgm}$. of thyroglobulin were injected intravenously in one dose into 5 dogs. The total and ultrafiltrable blood magnesium was determined at intervals of 15 minutes, 1, 5, and 24 hours. In each instance the increase in bound magnesium varied between 30 and 100 per cent over the control level (Table V). This increase occurred

TABLE V

Percentage of bound magnesium following the injection of thyroglobulin, thyroxin and horse serum intravenously into dogs

\begin{tabular}{|c|c|c|c|c|c|c|c|}
\hline \multirow{2}{*}{$\underset{\text { ber }}{\operatorname{Dog}}$} & \multirow{2}{*}{\multicolumn{2}{|c|}{ Dose }} & \multicolumn{5}{|c|}{$\begin{array}{l}\text { Percentage of bound } \\
\text { magnesium }\end{array}$} \\
\hline & & & $\begin{array}{l}\text { Con- } \\
\text { trol }\end{array}$ & $\begin{array}{c}15 \\
\min - \\
\text { utes }\end{array}$ & hour & $\begin{array}{c}5 \\
\text { hours }\end{array}$ & $\begin{array}{c}24 \\
\text { hours }\end{array}$ \\
\hline $\begin{array}{l}1 \\
2 \\
3 \\
4 \\
5\end{array}$ & $\begin{array}{l}\text { Thyroglobulin } \\
\text { Thyroglobulin } \\
\text { Thyroglobulin } \\
\text { Thyroglobulin } \\
\text { Thyroglobulin }\end{array}$ & $\begin{array}{l}50 \mathrm{mgm} . \\
00 \mathrm{mgm} . \\
00 \mathrm{mgm} . \\
00 \mathrm{mgm} . \\
00 \mathrm{mgm} .\end{array}$ & $\begin{array}{l}23.0 \\
25.5 \\
27.0 \\
29.1 \\
15.2\end{array}$ & $\begin{array}{l}36.8 \\
23.4 \\
15.3 \\
22.8 \\
26.2\end{array}$ & $\begin{array}{l}31.7 \\
51.0 \\
33.3 \\
32.8 \\
23.5\end{array}$ & $\begin{array}{l}46.5 \\
24.5 \\
35.0 \\
45.6 \\
24.6\end{array}$ & $\begin{array}{r}15.8 \\
17.0 \\
27.5 \\
37.5 \\
6.5\end{array}$ \\
\hline 6 & Thyroxin & 5 mgm. & 13.7 & 5.4 & 9.5 & 5.0 & 11.6 \\
\hline 7 & Horse serum & 5 cc. & 7.3 & 7.3 & 8.2 & 7.5 & 7.0 \\
\hline
\end{tabular}

within 1 to 5 hours after the injection. The injection of equivalent doses of thyroxine and horse serum produced no change in the percentage of bound magnesium. This would suggest that the thyroglobulin plays some rôle in binding magnesium and would further suggest that there is an increase of this substance in the blood of patients with hyperthyroidism. The fact that a considerable period of time elapses between the injection of the thyroglobulin and the increase in bound magnesium would indicate that there is no direct union between the ion and the protein, but rather that the latter sets into motion some mechanism which causes binding of magnesium. In vitro experiments failed to demonstrate any binding between thyroglobulin and magnesium. Further studies are being conducted to determine the various factors which operate to bind the blood magnesium.

\section{SUMMARY}

1. Total serum and ultrafiltrate magnesium determinations were made in 14 normal individuals, 5 patients with neurocirculatory asthenia, 7 patients with various muscular dystrophies, and in 31 patients with hyperthyroidism.

2. In the normal individuals the percentage of bound magnesium varied between 3.1 and 22.1 per cent.

3. The patients with neurocirculatory asthenia and various types of muscular dystrophy showed no change in the percentage of bound magnesium as compared to the normals.

4. The patients with hyperthyroidism showed a marked increase in the non-diffusible fraction of the total blood magnesium. The percentage of bound magnesium in these patients varied between 21.5 and 61.6 per cent.

5. No relationship was noted between the basal metabolic rate and the percentage of bound magnesium.

6. Following lugolization there is a considerable decrease in the non-diffusible magnesium fraction with a further drop and return to normal levels after thyroidectomy.

7. In two patients with myxedema, there was no circulating bound magnesium.

8. Thyroglobulin injected intravenously into dogs produces a considerable transient increase in the non-diffusible magnesium fraction suggesting that this protein plays some part in the binding mechanism.

9. The determination of the percentage of bound magnesium may serve as a means for diagnosing obscure and borderline instances of hyperthyroidism. 


\section{BIBLIOGRAPHY}

1. Watchorn, Elsie, and McCance, R. A., Inorganic constituents of cerebrospinal fluid; ultrafiltration of calcium and magnesium from human sera. Biochem. J., 1932, 26, 54.

2. Brull, Lucien, L'excrétion des phosphates par le rein et sa régulation. Archives Internat. de Physiologie, 1928, 30, 1.

3. Scholtz, Hans Georg, Utber Änderungen des physikalischen Zustandes von anorganischen Bestand- teilen des Serums durch gegenseitige Beeinflussung. Biochem. Ztschr., 1931, 231, 135. Arch. f. exper. Path. u. Pharmakol., 1930, 157, 133.

4. Briggs, A. P., Colorimetric method for determination of small amounts of magnesium. J. Biol. Chem., 1922, 52, 349.

5. Kuttner, T., and Lichtenstein, L., Micro colorimetric studies. II. Estimation of phosphorus: molybdic acid-stannous chloride reagent. J. Biol. Chem., $1930,86,671$. 